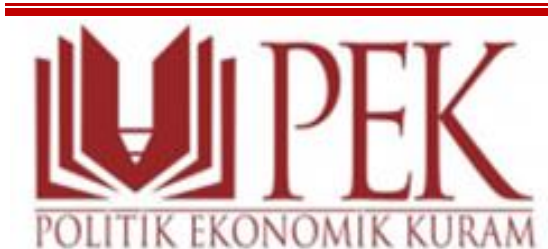

2020, Cilt 4, Sayı 2, 269-280

\section{POLİTIK EKONOMIK KURAM}

E-ISSN: 2587-2567

https://dergipark.org.tr/tr/pub/pek

Doi: $10.30586 /$ pek.798153

Makale Geliş Tarihi: 21.09.2020

Makale Kabul Tarihi: 09.11.2020

Araştırma Makalesi

\title{
Klasik Dönem Osmanlı Zanaatları: İktisadi Zihniyet İlkeleri Çerçevesinde Bir Değerlendirme ${ }^{1}$
}

Cumali BOZPINAR ${ }^{2}$

\author{
Classical Ottoman Crafts: An Evaluation within The Framework of Economic Mindset \\ Principles
}

\begin{abstract}
The economic structure of the Ottoman State had a pre-capitalism quality. Therefore, some principles are mentioned in the Ottoman economic mindset as they are applicable to all pre-capitalism societies. These principles are provisionalism, traditionalism, and fiscalism. In the study, Ottoman crafts in the Classical Period were examined under the headings of weaving, leather making and mining. The main result obtained is that Ottoman craft production was carried out within the framework of mindset principles in the Classical Period. Another conclusion is that the extra-economic seizure of social surplus by the power in pre-capitalist structures was also valid for the Ottoman State in the Classical Period.
\end{abstract}

Keywords: Ottoman crafts, Classical Period, provisionalism, traditionalism, fiscalism.

JEL Codes: B11, B25, B31, N15

$\ddot{\mathbf{O} z}$

Osmanlı Devleti'nin iktisadi yapısı kapitalizm öncesi bir niteliğe sahipti. Dolayısıyla tüm kapitalizm öncesi toplumlarda geçerli olduğu gibi Osmanlı iktisadi zihniyetinde bazı ilkelerden bahsedilmektedir. Bu ilkeler iaşe, gelenekçilik ve fiskalizmdir. Çalışmada Klasik Dönem'de Osmanlı zanaatları dokumacılık, dericilik ve madencilik başlıkları altında incelenmiştir. Elde edilen temel sonuç Klasik Dönem'de Osmanlı zanaat üretiminin zihniyet ilkeleri çerçevesinde yürütüldüğüdür. Diğer bir sonuç, kapitalizm öncesi yapılarda iktidar tarafindan toplumsal artığa ekonomi dışı yolla el konulmasının Klasik Dönem'de Osmanlı Devleti için de geçerli olduğudur.

Anahtar Kelimeler: Osmanlı zanaatları, Klasik Dönem, iaşe, gelenekçilik, fiskalizm.

\footnotetext{
${ }^{1} \mathrm{Bu}$ çalışmanın “Klasik Dönem'de Osmanlı Zanaatları” başlıklı bölümünde Bozpinar (2018)'dan yararlanılmış olup ilave kaynaklarla geliştirilmiştir. Bunun dışında çalışmada Bozpinar (2018)’ın genel olarak "Klasik Dönem'de Osmanlı zanaatları iktisadi zihniyet ilkelerine göre faaliyet göstermiştir” şeklindeki tespitinin yanında esas itibarıyla adalet dairesi kavramına ayrı bir bölümde yer verilerek iktisadi zihniyet ilkeleri ile adalet dairesi ilişkisinin ikincisinin birincinin "görünmeyen ruh”u olduğu ve söz konusu ilkeler çerçevesinde Klasik Dönem Osmanlı zanaat üretiminin İstanbul'un refahı ve ekonomik istikrarının sağlanması yönünde işlev gördüğü sonuçlarına ulaşılmıştır.

${ }^{2}$ Dr., Çevre ve Şehircilik Bakanlığı (Milli Emlak Genel Müdürlüğ̈̈), e-posta: cumalispontik@ gmail.com, orcid: 0000-0001-8760-5253.
} 


\section{Giriş}

Toplumların iktisadi zihniyetleri ile sahip oldukları maddi koşullar arasında bir ilişki bulunur. $\mathrm{Bu}$ ilişkinin açıklanmasına dönük olarak iki yaklaşım bulunmaktadır. İlki K. Marx ve F. Engels'in ortaya koydukları tarihsel maddeci yaklaşım olup üretim ilişkileri öne çıkarılır ve mekanik olmayan bir şekilde zihniyetin üretim ilişkileri kalıbını yansıttığı kabul edilir. Buna göre toplum tarafından üretilen artığa el koyma mekanizmasının karakteristiğini ilgili toplumda geçerli üretim ilişkileri şekillendirmekte olup bu mekanizmanın ilgili toplum için "doğal” kabul edilen ve gelenek, dinsel inanış $v b$. temelinde şekillenen bir zihniyet yanı da bulunmaktadır. İkinci yaklaşım ise Alman Tarihsel Okulu çizgisini izleyen M. Weber ve W. Sombart'ın görüşleri çerçevesinde şekillenmiş olup zihniyet öne çıkarılır ve zihniyetin özerk ya da bağımsız olarak toplumun sahip olduğu maddi koşulları belirlediği kabul edilir. Bu kapsamda kapitalizmin doğuşunu Weber'in Protestan ahlakına, Sombart'in ise Yahudiliğin gereklerine bağlarken Ülgener' in, Osmanlı toplumunda kapitalist girişimci tipinin ortaya çıkamamasında İslam dininin etkili olduğunu kabul ettiği belirtilebilir (Bozpinar, 2018: 3-4).

Kapitalizm öncesi toplumlarda benzer iktisadi zihniyet ilkeleri geçerlidir. Esas olarak zamanın ilkel sayılabilecek düzeydeki üretim teknolojisi ve ulaştırma imkânlarının yetersizliğine bağlı olarak piyasa kurumunun şekillenmemesinden dolayı toplumsal düzeni sağlamak ve devletin ihtiyaç duyduğu gelirleri toplamak için üretim ve dağıtım ilişkilerine müdahalede piyasa dış1 ilkelerden yararlanılmıştır. Bu ilkeler zamanın toplumlarının iktisadi zihniyetini şekillenmiştir. Kapitalist toplumlardan farklı olarak piyasa sisteminin ikincil bir rolde olması dolayısiyla böylesi toplumlar için geçerli iktisadi zihniyet ilkelerini "piyasa harici iktisadi zihniyet ilkeleri" olarak nitelendirmek mümkündür. Nitekim M. Genç kapitalizm öncesi bir yapıdaki Osmanlı toplumunda bazı iktisadi zihniyet ilkeleri bulunduğunu ortaya koymuştur. Bunlar iaşe, gelenekçilik ve fiskalizm ilkeleridir. İaşe ilkesi "iktisadi faaliyetlerde tüketiciye öncelik verilerek üreticisinden nihai tüketiciye ulaşmasına kadarki tüm aşamalarında sıkı bir devlet müdahaleciliğiyle piyasada mal ve hizmet arzının mümkün olan en yüksek düzeyde tutulması”, gelenekçilik ilkesi "iktisadi ilişkilerde daima kurulu düzenin korunması ve geleneksel kuralların gözetilmesi" ve fiskalizm ilkesi "iktisadi faaliyetlerde devlet gelirlerinin mümkün olduğu kadar yüksek düzeye çıkarılması ve ulaştığı düzeyin altına inmesinin engellenmesi amacının güdülmesi” olarak ifade edilebilir (Genç, 2012: 47-52; Bozpinar, 2018: 5).

$\mathrm{Bu}$ çalışmada kapitalizm öncesi bir üretim yapısı özellikleri gösteren Osmanlı Devleti’nde geçerli olan iktisadi zihniyet ilkeleri çerçevesinde Klasik Dönem ${ }^{3}$ Osmanlı zanaat üretimi incelenecektir. Önemle belirtilmelidir ki adalet dairesinin söz konusu ilkelerin meşruiyet temeli (görünmeyen ruhu) olduğu kabul edilmiştir.

Çalışmada kaynak derleme yöntemi kullanılmıştır. Bu kapsamda çeşitli ikincil kaynaklardan Klasik Dönem zanaat üretimi (imalat) faaliyetlerine ilişkin bilgiler derlenmiştir. Derlenen bu bilgiler zanaat grupları itibarıyla sistemleştirilmiş, bu gruplarda faaliyetlerin iktisadi zihniyet ilkeleri çerçevesinde yürütülüp yürütülmediği noktasında saptamalar yapılmış ve elde edilen bulgular değerlendirilerek bazı teorik çıkarımlarda bulunulmuştur ${ }^{4}$.

\footnotetext{
${ }^{3}$ Klasik Dönem olarak XV. yüzyıl ile XVIII. yüzyıl arası dönem kastedilmektedir. Bununla birlikte Osmanlı Devleti'ne egemen olan yapıların zihniyet, iktisadi kurumlar, dinamikler ve çelişkileriyle birlikte en açık biçimde XVI. yüzyıl incelenerek anlaşılabileceği belirtilmektedir. Ayrıntılar için $b k$. Yurtseven (2009), Pamuk (2010) ve İnalc1k (2013).

${ }^{4}$ Kapitalizm öncesi toplumlarda ve dolayısıyla Osmanlı toplumunda kapitalist yapıda bir piyasadan bahsetmek mümkün değildir. Bu toplumlarda piyasa işlevi gören yapılardan bahsedilebilir. Bu yapılarla ilgili olarak Osmanlı Devleti bağlamında bazı özellikler şöyle sıralanabilir: Hem çarşı hem de pazarlar ve panayırlar geleneksel olarak devlet kontrolünde olmuş, buralarda halk tüketim mallarını ve loncalar ham maddelerini tedarik etmişler ve
} 
Bozpinar, C. (2020), "Klasik Dönem Osmanlı Zanaatları: İktisadi Zihniyet İlkeleri Çerçevesinde Bir Değerlendirme", Politik Ekonomik Kuram, 4 (2), 270-280.

\section{Adalet Dairesine Kavramsal Bir Bakıș: İktisadi Zihniyet İlkelerinin "Görünmeyen Ruh"u}

Kapitalizm öncesi toplumlarda üretim ilişkileri birer bağımsız toplumsal ilişki görüntüsünde değillerdir. Böylesi yapıya sahip sosyoekonomik formasyonlarda toplumsal kurumların hem teşekkülünde hem yerine getirdikleri toplumsal işlevlerinde ideoloji birincil önemde role sahiptir. Her ne kadar bu toplumlar sosyoekonomik formasyanlarını mutlak surette siyaset temelinde düzenlemiş olmasalar da siyaset toplum hayatında ekonomik ilişkilerin kısmen ifadesi olarak yerleşmiştir. Dahası aynı toplumlarda iktisadi karaktere sahip olmadığı kabul edilebilecek inanç sistemlerine özgü ritüeller ve rutinler ile sosyal yapı unsurları, kurumsal yapılar, gelenek $v b$. ikincil nitelikte olmakla birlikte sosyal ilişkilerin yeniden üretimini belirlemişlerdir. Bu bağlamda Orta Çağ Avrupası'nda din, Avustralya Aborijin toplumunda akrabalık ilişkileri ve Klasik Yunan toplumunda tam anlamıyla ekonomik olmayan din gibi "sözde" üstyapı unsurlarının da üretim ilişkileri işlevi gördüğü belirtilebilir (Haldon, 1993: 44).

Orta Doğu tarihine bakıldığında bu coğrafyadaki toplumların da bu değerlendirmeden müstesna olmadığı, Antik Çağ'dan itibaren burada da iktidarın meşrulaştırılmasında bazı ideolojik söylemlerden yararlanıldığı görülmektedir. Bu söylemler arasında geleneksel olarak en geçerli olanı adalet kavramıdır. Osmanlı sosyoekonomik formasyonuna ilişkin literatürde "daire-i adliye" yani "adalet dairesi" olarak ifade edilen bu kavram kendisini oluşturan unsurları itibarıyla bir kapalı devreye benzetilebilir. Buna göre; adalet, dünyanın düzenini ve hatta kurtuluşunu sağlar; dünya ise duvarı devlet olan bir bağdır; devleti düzenleyen ise şeriattır; bununla birlikte hükümdar olmadan şeriat korunamaz; askersiz hükümdar toplumsal düzeni kontrol edemez; servet olmadan hükümdar asker toplayamaz; servetin kaynağı halktır ve halkı hükümdara tabi kılan ise adalettir. Başka bir deyişle adalet dairesinin birbirine bağlı unsurları; mülk yani devlet (hükümdarlık), asker, servet (hazine), halk (reaya) ve adalettir. Görüldüğü üzere iktidar ile adalet arasında karşılıklı bir bağımlılık mevcut olduğu aşikârdır ve dolayısıyla yetkisini keyfî bir şekilde kullanan iktidarın gayrimeşru addedildiği söylenebilir (Öz, 1999: 30). Adalet dairesi bağlamında toplum birbirine bağlı eşit olmayan parçalardan oluşmuştur. Üstelik bireylerin, bulundukları parçada çakılı kalmaları gerekli görülmüştür. Bu anlamda adalet, bunların bulundukları yerde tutulması olmuştur (Berkes, 2013: 48). Başka bir deyişle Osmanlı zihniyetinde adalet, toplumun denge durumu anlamına gelmiştir (Berkes, 2017: 180) ${ }^{5}$. Bu ideolojik söylem, ideolojik boyutundan arındırıldığında ise kavramın somut bir şekilde billurlaşarak şu içeriğe sahip olduğu kabul edilebilir: Kapitalizm öncesi toplumlarda ortaya çıkan artığın iktidar güçleri tarafından ele geçirilmesi adaletin bir gereğidir ve bu da statüleri ideolojik olarak meşrulaştıran dinsel inanışa dayandırılmaktadır. Böylece tarih boyunca Orta Doğu toplumlarında iktidarlar tarafından meşruiyetlerini temin etmek üzere adalet dairesi kanalıyla ideolojik bir şekilde "ekonomik artık üretiminin siyasi düzenin otoriteler tarafından adil bir şekilde yönetilmesine bağlı olduğu" aşılanmıştır (Keyder, 1989: 28).

Osmanlı iktisadi zihniyet ilkeleri özelinden Klasik Dönem Osmanlı zanaat üretimi değerlendirildiğinde, aşağıda zanaat grupları itibarıyla anlatılacağı üzere, adalet dairesinin söz konusu ilkeleri birleştirici bir ruha sahip olduğu kabul edilebilir. Üretici açısından katlanılması gereken yükümlülüğün objektif olarak belli bir standart ölçüsü saptanmamıştır yani üretici katlanabildiği sürece "yükümlülüğünün" şiddeti artırılabilir. Bunun dişında adalet dairesinin unsurlarının birbirine eklemlenmesi itibarıla kapalı bir devre algısı yaratılsa da üreticilerin

\footnotetext{
buradaki ticari işlemler vergilendirilmiştir. Diğer taraftan Osmanlı çarşılarında devlet loncalar kanalıyla kontrol sağlamıştır. Ayrıntılar için bk. Özcan (2007), Özveren (2007) ve Bozpinar (2018).

5 Tımar sistemi de bu kapsama dâhildir. Osmanlı yöneticileri “denge”yi bozmamak adına kendilerinden önceki sosyal formasyonların toprak yönetimlerini değiştirmeden uygulamaya devam etmişlerdir. Ayrıntılar için $b k$. Barkan (1980: 815-28).
} 
ürettiği servetin tamamının askeri masraflara gitmediği yani devrede bir "kaçak" olduğu mantıksal bir açıklığa sahiptir. Bize göre bu "kaçak" İstanbul'in refahı ve ekonomik istikrarı için kullanılmıştır ${ }^{6}$.

Böylece Osmanlı iktisadi zihniyet ilkelerinin Klasik Dönem Osmanlı zanaat üretiminde ortaya çıkan artığın İstanbul'un refahı ve ekonomik istikrarını sağlamak yönünde işlev gördügü kabul edilebilir.

\section{Klasik Dönem'de Osmanlı Zanaatları}

Osmanlı zanaatları dokumacılık, dericilik ve madencilik başlıkları altında incelenecektir. Bununla birlikte Osmanlı şehir çarşıllarında besin işleme zanaatlarının da önemli bir yere sahip olduğu belirtilmelidir.

Klasik Dönem'de Osmanlı zanaatları üretim merkezleri itibarıyla gruplandırılabilir ve böylece zihniyet ilkeleri çerçevesinde incelenebilir. Bazı zanaat üretim merkezlerinde ilgili zanaatın ham madde üretiminin de yapılıyor olması halinde böylesi durumlar ayrıca belirtilecektir ${ }^{7}$.

Başka bir husus Osmanlı arşiv belgelerinde zanaatkârlarla ilgili oldukça çok sayıda kayıt bulunmakla birlikle konuyla ilgili istatistiki bilginin makroekonomik bir değerlendirme yapılması noktasında oldukça yetersiz düzeyde olduğudur. Bunun yanında kapitalizm öncesi toplumlarda sıklıkla görüldüğü gibi mevcut bilgiler üretimden ziyade dağıtım süreçleriyle ilgilidir (Faroqhi, 2002: 168).

\subsection{Dokumacılık}

Osmanlı Devleti'nde Klasik Dönem'de zanaat üretimi şeklinde yürütülen dokumacılık faaliyetlerinin başta ipekli, pamuklu, yünlü ve diğer dokumac1lık ${ }^{8}$ olduğu belirtilebilir.

Klasik Dönem'de, İran'dan gelen ham ipeğin işlendiği ipekli dokumacılığı merkezleri Bursa, İstanbul, Amasya, Tokat, Mardin, Diyarbekir, Halep ve Sakız olmuştur ${ }^{9}$. Bunlar arasında Bursa öne çıkmaktadır (İnalcık, 2009: 270; Kıvrım ve Elmacı, 2011: 717). Daha az önemde olmak üzere ipek üretimi/dokumacılığı yapılan yerler ise Kıbrıs, Bilecik, Mora, Lübnan, Şam ve Edirne olmuştur.

\footnotetext{
6 Zamanın ilkel sayılabilecek düzeydeki üretim teknolojisi ve ulaştırma imkânlarının yetersizliği iaşe ilkesinin uygulanmasını zorunlu kılmıştır. Bu objektif şartlar dışında siyasi bir şart olarak yiyecek kıtlığının yol açabileceği isyan tehlikesi belirtilebilir. Osmanlı tarihinde kıtlığa bağlı isyanlar özellikle İstanbul için büyük önem taşımıştır (Bozpinar, 2018: 24). Konuyla ilgili olarak Faroqhi (2017: 193)'den şu aktarma uygun olacaktır: “İstanbul birkaç yüz bin kişilik bir şehirdi ve Osmanlı padişahları ... bu büyüklükte nüfuslardan endişe duyan erken modern dönemin diğer hükümdarları gibi, başkente erzak tedariki için yalnızca piyasaya bel bağlamazlardı. Unutmamalı ki, iktidar merkezinin bu kadar yakınındaki kıtlıklar -ve bunların neden olabileceği yiyecek isyanları- padişah ve vezirlerin siyasi ve çoğu zaman da fiziki yaşamlarını tehlikeye atıyordu...” Diğer taraftan iaşe ilkesini her ne kadar Genç (2012) sistemleştirmiş olsa da Genç (2012)’ten önce de konu başka yazarlar tarafından çalışılmıştır. Bunlar arasında Ülgener (2006) öne çıkmaktadır.

7 Çalışmada, tarım dışı üretim faaliyetleri incelenmiştir. Yılmaz (2012)’ın ifadesiyle Osmanlı Devleti’nde “piyasanın karşıtı pazar” geçerli olmuştur. Osmanlı Devleti’nde "piyasanın karşıtı pazar”da loncaların (zanaat üretiminin) ihtiyacı olan ham maddelerin de tedarik edilmesiyle bağlantılı olarak tedarikçilerin tarımsal üreticiler olduğu göz önünde bulundurularak Osmanlı zanaat üretimi ile Osmanlı tarımı arasında bir bütünleşik ilişkinin geçerli olduğu unutulmamalıdır. Ayrıntılar için $b k$. Bozpinar (2018).

${ }^{8}$ Bu kategoriye kenevir ve keçi kılından çuval ve benzeri kaba bezler ve keçi kılından at örtüsü ve yem torbası ile at kılından çuval üretimi girmektedir.

${ }^{9}$ Ayrıntılar için $b k$. Dalsar (1960), Şimşirgil (1995), Tabakoğlu (2000), Faroqhi (2008), İnalcık (2009), Kıvrım ve Elmac1 (2011), Tekin (2013) ve Faroqhi (2014).
} 
Klasik Dönem'de Bursa ipekli dokumacı zanaatkârları loncalar şeklinde örgütlenmiştir. Kendi aralarından seçtikleri tecrübeli ustalardan oluşan "ehl-i hibre" adlı kurul; ipekli kumaş üretim standartları ile işçilik ücreti, satış fiyatı ve kâr oranı $v b$. temel standartları belirlediği gibi çalışanlara karşı ustaların çıkarlarını korumakla da görevli olmuştur. İşyeri sahipleri de çalıştırdıkları işçileri ehl-i hibreye kaydettirmek zorunluluğu içinde olmuşlardır. Ayrıca ustasıyla ihtilafa düşen kalfa ehl-i hibrenin izni olmadan başka bir işyerinde işe başlayamamıştır. Bunun yanında işyeri sahipleri kabul etmiş olsalar bile ehl-i hibre ehil olmayan kimselerin dokumacı olarak istihdam edilmesine izin vermemiştir. Böylece ehl-i hibrenin iş gücünün hareketliliğini kısıtlayıcı ve loncaların dışarıya kapalı üretim yapısını güçlendirici yönde işlev gördükleri anlaşılmaktadır. Osmanlı loncalarında üyeliğe kabul için temel şart olarak zanaatkârlar ordu akçesi adıyla devlete vergi ödemiştir. Diğer bir özellik kervanlarla İran'dan getirilen ham ipeğin lonca görevlisi yiğitbaşı tarafından herkesin gözü önünde satın alınıp lonca ustaları arasında paylaştırılması olmuştur. Bu uygulamada bir zanaatkârın ham maddenin tümünü satın alarak karaborsa yapmasının engellenmesi amacı güdülmüştür (Aktar, 1990: 145, 150). Böylece Klasik Dönem'de Bursa ipekli dokumac1 loncalarının daha önce açıklanan üç ilkenin tam bir uygulaması olduğu görülmektedir.

Diğer taraftan fiskalizm ilkesi çerçevesinde Klasik Dönem'de Bursa ipek sektöründe değerlendirebilecek başka bir husus mizan-1 harir (ipek kantarı) vergisidir. Bu kapsamda mukataa değerinin 1487'de 6 milyon akçe, 1508'de 5,45 milyon akçe, 1512'de 7,35 milyon akçe, 1513'de 7,3 milyon akçe, 1521'de 2,1 milyon akçe, 1523'de 3 milyon akçe, 1531'de 3,1 milyon akçe, 1540 'da 2,9 milyon akçe, 1542 'de 3,8 milyon akçe, 1557'de 4,2 milyon akçe, 1558 'de 4,1 milyon akçe, 1577 'de 2,38 milyon akçe, 1598' de 4,55 milyon akçe, 1606'da 5,2 milyon akçe ve 1638'de 3,12 milyon akçe olduğu belirtilebilir (İnalcık, 2009: 278) ${ }^{10}$.

Ne yazık ki Bursa dışında Osmanlı ipek sektörüne ilişkin bilgiler çok ender niteliktedir. $\mathrm{Bu}$ konuda Amasya'daki mizan-1 harire ilişkin veriler bulunmaktadır. Bu şehirde mizan-1 harir mukataası için 1552 yılında 40.000 akçe ödenmiştir. 1576 y1lı için bu mukataa için ödenen 45.000 akçe, 171.000 akçe olan şehrin aynı yıl toplam gelirinin \%26'sına karş1lık gelmiştir. Bununla birlikte Amasya'ya getirilen ipeğin kısmen daha önce Tokat'ta vergilendirilmesine bağlı olarak sahiplerine \%50 oranında indirim yapıldığı bilinmektedir (Kıvrım ve Elmacı, 2011: 718; Faroqhi, 2014: 179). Mizanda tartılan ipeğin hepsinin Amasya'da işlenip işlenmediği kesin olarak saptanamamakla birlikte (Faroqhi, 2014: 179), Amasya'da ipekli dokumacılı̆̆ zanaatının bulunduğunu söyleyebiliriz. Daha büyük olan Tokat mizanının 1553 yılı mukataa değeri 77.000, sonraki yıl ise 161.039 akçe olarak belirtilmektedir. Bunun dışında Batı Anadolu ipek sektörüne ilişkin sayısal olmayan bazı bilgiler bulunmaktadır. Bursa'da yapılan değerli kumaş üretiminin yayıldığı yerlerden Bilecik'te sırma işlemeli bir tür kadife olan zerbaft da dokunmuştur. Zerbaft zanaatkârının düşük nitelikte üretim yapmaları dolayısıyla kadıya şikâyette bulunulmuş, bunda devam etmeleri halinde Bursa'ya gönderilmeleri düşünülmüştür (Faroqhi, 2014: 179-80). Başka bir ham ipek üretim yeri Kıbrıs olmuştur. Osmanlı Devleti’nde XVII. yüzyıldan itibaren dut ağacı yetiştirilmesinin önem kazanmasıyla adada ipek üretimi yapıldığı belirtilmektedir: XVII. yüzyılda yılda 8.000 okka, XVIII. yüzyılda yılda 13.000 okka (Özkul, 2010: 289, 293). Diğer bir üretim bölgesi bugünkü Lübnan olmuştur. 1528 yılında Beyrut'ta mizan-1 harir ve dellaliye ${ }^{11}$ olarak 10.000 akçe elde edilmiştir. Bu bölgede diğer

\footnotetext{
${ }^{10}$ Çalışmanın tamamında belirtilen değerlerin makroekonomik perspektiften bir karşılaştırma yapmaya imkân verebilmesi için bazı değer ölçütlerinin ve Osmanlı mali büyüklüklerinin belirtilmesi uygun olacaktır. 1 altın 3,5 gr, 10 akçe (II. Mehmet döneminde) ve 60-70 akçeye (1520-1570 dönemi), 1 düka altını ise 300 akçeye (1617-8: I. Mustafa dönemi) eşit olmuştur. 1475 yılı Osmanlı Devleti'nin tımar gelirleri hariç toplam geliri 1.760.000 düka altını, tımar gelirleri de eklendiğinde 3.000.000 düka altını olarak tahmin edilmektedir. Ayrıntılar için $b k$. İnalcık (2009: 93-141).

${ }^{11}$ Gümrüklere getirilen ipekten alınan vergi.
} 
önemli merkezler Sayda ve Trabluşşam olmuştur. Trabluşşam'daki mizan-1 harirden 1519'da 25.000 akçe, 1571 'de 80.000 akçe gelir elde edilmiştir. Lübnan'a yakın Şam da başka bir ipek merkezi olmuştur. Burada ham ipek üreticiliği yapılmamış, Lübnan'dan getirilen ham ipek işlenerek satışa hazır hale getirilmiştir (Çelik, 2016: 278-280). Mora'da da ipek üretimi yapıldığı ve Bursa ipekli dokumacılığına ham madde sağlandığı belirtilmektedir (Altun, 2007: 103). XV. yüzyılın ikinci yarısı ile XVI. yüzyılda ipekçiler çarşısı bulunan Tokat başka bir üretim merkezi olmuştur. Tokat'ta bu dönemde hem ham ipek üretilmiş hem de İran'dan ham ipek ithalatı yapılmıştır. Ayrıca ipekli dokumacılık faaliyetinin de gerçekleştirildiği bu şehirde 1550, 1554 ve 1574 yıllarında mizan-1 harir mukataasının yıllık 266.666 akçe olduğu belirtilmektedir (Şimşirgil, 1995: 188). İpekli dokumacılığı gelişmiş olmakla birlikte ham maddenin Bursa ve Tokat'tan geldiği Halep de önemli bir merkez olarak belirtilmektedir (Tekin, 2013: 684). Daha az bilgi sahibi olabildiğimiz yerlerden Edirne'de ipek üretimi ve ipekli dokumacılık faaliyetinde bulunulmuştur (Şahin, 2006: 46-7).

Klasik Dönem'de Osmanlı ülkesinde dokumacılık zanaatında pamuk ve pamuk ipliği ihracatının sürekli yasak olduğu görülmektedir. Bunun nedeni ordunun çadır talebinin yanı sıra donanmanın yelken gereksinimi olmuştur (Faroqhi, 2014: 157-8). Bu yasaklama, iaşe ilkesinin bir uygulaması olarak değerlendirilebilir. Dokumacılık zanaatında iaşe ilkesiyle bağlantılı başka bir uygulama tersanenin kendir ihtiyacı olmuştur. Tersanenin kendir ihtiyacı kısmen Kıbrıs ve Trakya yöreleriyle Aydın ve Saruhan vilayetlerinden karşılanmıştır fakat esas kendir kaynağı Samsun yöresi olmuştur. Tersanenin ihtiyacının düzenli bir şekilde sağlanabilmesi için Samsun ve Terme yakınlarındaki kendir haslarının ahalisi düzenli olarak kendir teslim etmekle yükümlü tutulmuşlardır (Faroqhi, 2014: 162-3).

Dokumacılık zanaatıyla ilgili olarak başka bir husus ham pamuk ve işlenmiş ürün ticaretinin büyük şehirlerde yoğunlaşmış olduğudur. Kayseri'de Bayram Paşa Vakfi'na ait Kapan Hanı'nda pamuk kantarlarının, Ankara'da Pamuk Hanı diye bilinen bir yapının bulunduğu belirtilmektedir. Anadolu'nun muhtelif şehirlerinde de çoğu pamuktan eğrilmiş iplik satışının yapıldığ üretim önemli miktarda olmalı ki 1573-74 yılında kapan ${ }^{12}$ yerleştirilmiş ve kullanımını zorunlu kılınmıştır (Faroqhi, 2014: 168). Klasik Dönem'de önemli Osmanlı şehirlerinde ham pamuk ve işlenmiş ürünler için kapanların varlığı, fiskalizm ilkesinin bir uygulaması olarak kabul edilebilir.

Yünlü kumaş dokumacılığı da Klasik Dönem Osmanlı dokumacılık zanaatında önemli bir yerdedir. Öyle ki yünlü, kilim ve halı dışında ham yün de önemli bir iç ve dış ticaret kalemi olmuştur. En azından XVI. yüzyılın ikinci yarısında ham yün ihracatının yasak olmadığı belirtilmektedir. Yalnızca aşırı miktarda ihracat nedeniyle yöre zanaatkârları ham madde sıkıntısı çektiklerinde onları koruyacak yasaklar uygulanmıştır. Buna örnek olarak Manisalı

\footnotetext{
${ }^{12}$ Osmanlı Devleti’nde büyük şehirlerde özellikle hububat türünden ihtiyaç maddelerinin toptan alınıp satıldığı yere kapan denmiştir. "Büyük terazi, kantar" anlamına gelen sözcüğün Latince "campana" olarak Farsça'ya, buradan kabbân şeklinde Arapça'ya geçtiği, Türkçe'ye ise kapan olarak girdiği ileri sürülmektedir. Kapan kavramı Osmanlı Devleti'nde genel olarak un kapanı, bal kapanı, yağ kapanı gibi satılan malın adıyla birlikte kullanılmak suretiyle büyük tartı aleti anlamından çıkıp günümüz toptancı hallerine veya tahıl borsalarına benzeyen yerlerin adı olmuştur. Osmanlı Devleti'nde un, yağ ve baldan başka tahıl, kahve, tütün, ipek, pamuk, kumaş ve çeşitli dokumalar üreticiden satın alınarak başta İstanbul olmak üzere büyük şehirlerdeki kapanlara getirilmiş, buralarda kadı nâibinin (yardımcısının) gözetiminde zanaatkâr temsilcilerinin de huzurunda mallar tartılıp ağırlık, kalite ve çeşidine göre vergi ve narha tâbi tutulduktan ve fiyatları belirlendikten sonra zanaatkâr aracılığıyla tüketiciye arz edilmiştir. Osmanlı Devleti'nin kuruluş döneminde vakıf kurumlarının giderlerini karşılamak üzere bunların yanlarına kapanlar da inşa ettirilmiştir. Orhan Bey zamanında Bursa'da tartı işlerinin yapıldığı Emir Hanı ile Ulucami'nin batı tarafinda Kapan Hanı adlı yapıların bulunduğu bilinmektedir. Kapanlardaki işlemler önceleri devlet adına kethüda gibi memurlar tarafindan yürütülürken zamanla ortaya çıkan mali krizlere bağlı olarak iltizama verilmeye başlanmıştır. Ayrıntılar için $b k$. Aynural (2001).
} 
velense dokumacılarının İstanbul'dan bir ferman alarak ham madde kaynakların korumaya çalışmaları belirtilebilir (Faroqhi, 2014: 171-3). Başka bir örnekte 1492 yılında İspanya'dan ayrılıp Selanik'e yerleşen ve yeniçeri üniformaları kumaşları dokutulan Yahudi dokumacılara ham yün alımları için öncelik hakkı verilmiş, diğer tüccarlar ancak Selanikli dokumacıların gereksinimlerine yetecek miktarı almalarından sonra ham yün alabilmişlerdir (Faroqhi, 2002: $168)^{13}$. Böylece daha önce belirttiğimiz böylesi yasakların iaşe ilkesine bağlanılabileceği tespitimiz yünlü dokumacıllğı bağlamında da desteklenmiş olmaktadır.

Buraya kadar ihracat yasaklarının iaşe ilkesi çerçevesinde uygulamalar olduğu belirtilmişti. Buna göre ihracat yasaklarının aynı zamanda loncaların yararına düşünüldüğü anlaşılmaktadır. Bu sayede ihracat yasaklanarak yerli zanaatkârın yani ilgili lonca üyelerinin ham madde tedariki sağlanmıştır. Bunun yanında ihracat yasaklarının loncalardan devlete gelir sağlanmasının bir aracı olduğu ve dolayısıyla fiskalizm ilkesi çerçevesinde uygulamalar olduğu söylenebilir. Burada iaşe ilkesiyle bağlantılı belirtilmesi gereken özel bir uygulama XVI. yüzyıl boyunca Ankara'da bir bolluk havası oluşmasına katkısı olan canlı bir tiftikten kumaş (sof) ihracatıdır ki başlıca müşterisi Venedikli, Leh ve İngiliz tüccarları olmuştur. Tiftiğin Anadolu dışında hiçbir yerde bulunmayan bir tür keçiden elde edilmesine bağlı olarak gerçekleşen bu canlılığ 1 , yerel ihtiyaç fazlasının ihracatı anlamında iaşe ilkesinin bir uygulaması olarak kabul etmek mümkündür.

Hayvan kıllarından çeşitli bezlerin üretiminde de zihniyet ilkelerinin uygulandığını görmek mümkündür. Klasik Dönem'de Anadolu'nun çeşitli yörelerinde kenevir ve keçi kılından çuval ve benzeri kaba bezlerin yapıldığ bilinmektedir. Bazı şehirler bu üretim faaliyetinde uzmanlaşmışlardır. Çuval bezi üretilmeyen Bursa'nın ihtiyacı bu işte uzmanlaşmış Karasi vilayetindeki Balıkesir'den getirilerek karşılanırken Bursa'nın doğusunda ormanlık ve dağlık bir bölgedeki Göynük kasabası ise keçi kılından at örtüsü ve yem torbası yapımında uzmanlaşmıştır. Daha büyük şehirlerde olduğu gibi burada da zanaatın loncaların denetiminde olduğu, loncaların ehl-i hibrenin yanı sıra yiğitbaşı ve kethüda adlı yöneticilerinin bulunduğu belirtilmektedir. Kayıtlarda Edincik, Manyas, Mihaliç (Karacabey) ve Erdek kazalarından keçi kılı elde edildiği bilgisi yer almakta ve buna dayalı olarak bu işin Bursa yöresindeki tüm köylerde de yapıldığı tahmin edilmektedir. Birgi ve Bayındır bölgesinde kapanda tartılması gerekli mallar arasında keçi kılının da sayılıyor olmasından burada keçi kılı üretiminin önemli bir üretim faaliyeti olduğu anlaşılmaktadır. Keçi kılından çuval bezi yapımının ise Anadolu'da yaygın olduğu ve pek çok şehirde bu işle uğraşan zanaatkârlara ayrılmış özel sokaklar bulunduğu belirtilmektedir. En azından Güney Anadolu'da keçi kılı yanında at kılının da çuval yapımında kullanıldığı anlaşılmaktadır. Ordunun ihtiyaç duyduğu çuvalların tedarikine ilişkin Adana kadı ve sancakbeyine yazılmış bir fermandan at kılından ve başka maddelerden yapılmış çuvalların yakındaki Üzeyir sancağından sağlanabildiğini öğrenmekteyiz (Faroqhi, 2014: 1734).

Böylece Klasik Dönem'de Osmanlı Devleti'nde keçi kılından at örtüsü, yem torbası ve çuval bezi yapımı zanaatının hemen hemen tüm büyük şehirlerde lonca denetiminde olduğu, Birgi ve Bayındır bölgesinde keçi kılı kapanı bulunduğu ve ordunun ihtiyacı çuvalların tedariki için zaman zaman ferman çıkarıldığı anlaşılmaktadır. Bunlar, Osmanlı iktisadi zihniyet ilkeleri

\footnotetext{
${ }^{13}$ Osmanlı yöneticilerinin nezdinde Yahudiler ekonomik açıdan etkin ve siyasal açıdan güvenilir bir unsur olarak görülmüştür. Bu anlamda Kıbrıs'ın Venedikliler'den alındığı 1571 sonrası yıllarda, kutsal topraklardaki Safed'e gitmekte olan Selanikli Yahudiler'in adada alıkonularak yerleştirilmesinde, Osmanlı yöneticilerince adadaki tebaanın çoğunluğunu oluşturan Hristiyanlar'ın tersine Yahudiler'in Bizans'ın ihtişamına özlem duymadıklarının ya da Osmanlı yönetiminden kurtulma arzularının bulunmadığının bilinmesinin etkili olduğu belirtilmektedir. Ayrıntılar için $b k$. Lewis (2011).
} 
çerçevesinde şöyle ifade edilebilir: Lonca denetimi her üç ilkenin uygulaması iken kapan fiskalizmin ve ordunun çuval ihtiyacı için ferman çıkarılması iaşe ilkesinin uygulamasıdır.

Klasik Dönem'de Osmanlı ülkesinde dokumacılık zanaatıyla ilgili son husus dokuma üretimi yapılan yerlerde boyahanelerin de bulunduğudur. Boyahane kimi zaman gerçek bir işyeri kimi zaman bir mali birim anlamında kullanılmıştır. Buralarda vergileme söz konusu olmuş ve iltizama verilmişlerdir (Faroqhi, 2014: 182-9). Boyahanelerde vergilemenin söz konusu olmas1 ve buraların iltizama verilmesi fiskalizm ilkesinin bir uygulamasıdır.

\subsection{Dericilik}

Osmanlı ülkesinde dericilik Klasik Dönem'de gelişmiş durumdadır ki Selçuklu döneminden beri bu faaliyetin yaygın olduğu bilinmektedir. Derici zanaatkârına debbağ denmiştir (Tabakoğlu, 2000: 225). Debbağların loncalar şeklinde örgütlendikleri anlaşılmaktadır. İstanbul ve Manisa debbağ loncalarının başkanlarından "ahi baba" diye söz edildiği belirtilmektedir. Bununla birlikte XVI. ve XVII. yüzyıllara ilişkin belgelerde Anadolu ve Balkan şehirlerinde tüm debbağları kapsayan bir örgütün varlığına ilişkin bir kanıt bulunmadığı anlaşılmaktadır (Faroqhi, 2014: 193-4).

Klasik Dönem'de Osmanlı Devleti'nde dericilik zanaatında iaşe ilkesi uygulamalarına ilişkin şunlar belirtilebilir: 1600 yılında saray için çalışan ayakkabıcılar genel olarak sadece sahtiyan kullanmışlardır ve saray için alınan ayakkabılar arasında Manisa sahtiyanından yapılanlar bulunmaktadır (Faroqhi, 2014: 199-200). Konya, Akşehir ve Seydişehir'de üretilen sahtiyan ve meşinin önemli miktarı yine İstanbul'a gönderilmiştir ${ }^{14}$. İstanbul'da deri kıtlığ baş gösterdiğinde bu yörelerin kadılarına başkentin ihtiyacını karşılamakla yükümlü oldukları hatırlatılmıştır. XVI. yüzyılda deri ticaretinde ardiye işlevi gören Sinop ve Samsun limanlarındaki kadı ve gümrük görevlilerine İstanbul dışında hiçbir yere sahtiyan ve meşin gönderilmemesini sağlamakla yükümlü oldukları bildirilmiştir. Sahtiyan ve meşinin ihracatı da Osmanlı ülkesinin başka vilayetlerine satılması da yasaklanmıştır (Faroqhi, 2014: 206-8).

Diğer taraftan Klasik Dönem'de Osmanlı Devleti'nde Anadolu'ya yakın yerlerde de deri ticaretinin gelişmiş olduğu görülmektedir. XVII. yüzyıl ortalarına kadar Osmanlı ülkesinin önemli ticaret merkezlerinden biri olan Halep'te özel sahtiyan kapanlarının bulunduğu belirtilmektedir. O dönemde Venedikli bir tüccar Fransa ve Hollanda'ya ihraç edilen farklı deri türlerinden söz ettiğinden Halep'teki kapanın ihracat için kullanılıyor olduğu tahmin edilmektedir (Faroqhi, 2014: 206). Bununla birlikte, yukarıda belirttiğimiz sahtiyan ve meşin ihracatının yasak olduğu bilgisi dikkate alındığında Halep’teki ihracatın gön deriyi kapsaması ya da Halep'in, sahtiyan ve meşin ihracatını kapsar şekilde özerk olması muhtemeldir. Böylece Halep'teki özel sahtiyan kapanları fiskalizm, Faroqhi (2014)'nin bu kapanların ihracat için kullanıldığı bilgisine dayanılarak da iaşe ilkesi uygulamalarının birer örneği durumundadır.

\subsection{Madencilik}

\footnotetext{
${ }^{14}$ Belgelerde sahtiyan, meşin ve gön olmak üzere üç deri çeşidinden bahsedilmektedir. Sahtiyan genellikle keçi derisi olup tabaklanarak boyanmış ve cilalanarak pahalı ayakkabı yapımında kullanılmıştır (Sahtiyan, t.y.). Genel olarak deri ile aynı anlamda kullanılmasına rağmen meşinin, 1600 dolaylarında göreli olarak ucuz bir deri çeşidi kullanıldığı anlaşılmaktadır. 1600 yılında saray için sipariş edilen bir çift terliğin Manisa sahtiyanından yapılması halinde 40 , meşinden yapılması halinde ise 25 akçe ödendiği belirtilmektedir. Gönün anlamı daha belirsiz olup kaba bir deri türü olduğu kabul edilmektedir. XV. yüzyıl sonu ve XVI. yüzyıl başlarına ilişkin İstanbul narh listelerinde su sığırı gönünden yapılmış ayakkabılar da yer almıştır. Sığır derisinden gön yapımında Makedonya'daki Yenice-i Karasu şehrinin uzmanlaştı̆ğ belirtilmektedir (Faroqhi, 2014: 199-200).
} 
Bozpinar, C. (2020), "Klasik Dönem Osmanlı Zanaatları: İktisadi Zihniyet İlkeleri Çerçevesinde Bir Değerlendirme", Politik Ekonomik Kuram, 4 (2), 270-280.

Klasik Dönem'de Osmanlı ülkesinde para sisteminin ve ordunun gereklerine paralel olarak madencilik gelişmiştir (Tabakoğlu, 2000: 231).

Madenci zanaatkârları maden üretimi yapılan merkezlerde bulunduğu gibi bunlara uzak şehirlerde de faaliyet göstermişlerdir. Böylece kaynak sınırlılığına rağmen ayrıntılı bir şekilde ele alınması her zaman mümkün olmayan iç ticaretin pek çok büyük şehri madencilik merkezlerine bağladığ 1 varsayılabilir. Bu tür ilişkiler en açık biçimde İstanbul örneğinde görülmektedir. Bununla birlikte önemli miktarlarda işlenmemiş maden Anadolu şehirlerindeki zanaatkâr atölyelerine ulaşmış olmalıdır.

XVI. yüzyılda Anadolu'daki madencilik merkezleri arasında hakkında en çok belge bulunanı durumundaki Küre madenleri Osmanlı yönetiminin denetiminde olmuştur. XVI. yüzyllın ikinci yarısından sonra Osmanlı yönetiminin çeşitli madenlerin işletmesini iltizama çıkardığı bilinmektedir. Bununla birlikte Osmanlı yönetiminin Küre'de üretilen bakırın tümünü istediği zamanların da olduğu belirtilmektedir. 1582 yılı tahrir defterine göre Küre madenlerinden yılda 26.228 men $(302.147 \mathrm{~kg})$ saf bakır elde edilmiştir. 1530-1582 döneminde Küre'de çıkarılan bakırın değeri \%22 oranında artarak 2.255.381 akçeden 2.752 .940 akçeye yükselmiştir. XV. yüzyıl tahrir defterinde Küre'de bakır eşya zanaatkârlarından hiç söz edilmemekle birlikte kayıtlarda geçen "haddad"ların (demircilerin) aslında bakırcı olduğu tahmin edilmektedir. XVI. yüzyılın ikinci yarısında ise Küre'ye bakır işleyen zanaatkârların yerleştiği, Osmanlı yönetimi için bakır ibrik yapan-onaran ibrikçilerin varlı̆̆ bilinmektedir ${ }^{15}$. Buradan Osmanlı yönetiminin Küre zanaatkârlarına epeyce iş verdiği anlaşılmaktadır. Nitekim sadece bir örnekte, üç ustanın 7.976 vukiye $(10.209 \mathrm{~kg})$ bakır kullanarak 47 yeni ibrik ve 17 ibrik altı yapma işini aldığ görülmektedir (Faroqhi, 2014: 214, 218, 221-2).

O dönemde Osmanlı yönetiminin talebinin yanı sıra halkın da bakırdan eşyaya yönelik bir talebi mevcut olmuştur. Bunun bir nedeni dönemin insanının bakır mutfak eşyasına gerektiğinde satılabilecek bir tür yedek akçe gözüyle bakmasıdır. XVIII. yüzyılda övgüye değer bulunan Tokat bakırcılarının ham maddelerinin önemli bir kısmını ve köy bakırcılarının da zaman zaman devlete verilmeyen bakırı Küre'den aldıkları görülmektedir. Bunun dışında Sivas ve Amasya bakırcılarının bakırı Küre'den aldığı anlaşılmaktadır. Bununla birlikte Osmanlı yönetiminin doğuya bakır taşıyan kervanlara bu değerli madenin İran'a ihraç edilmesi ihtimaline karşı her zaman kuşkuyla yaklaşmasından dolayı bakır almak isteyen bakırcılar Küre kadısına kendi şehirlerinin kadılarından aldıkları belgeleri sunarak iyi niyetlerini kanıtlamakla zorunlu tutulmuşlardır. Bu yapılsa dahi Sivas, Amasya ya da Tokat'a dönmeden önce aldıklarını İstanbul'a taşımaya zorlanabildikleri ve araç-gereç ve atölye bulamamalarından dolayı muhtemelen İstanbul'a getirdikleri bakırı yine burada sattıkları belirtilmektedir (Faroqhi, 2014: 223).

Böylece Klasik Dönem'de madenciliğin devlet denetiminde olduğu, iltizama verildiği ve ihracatın yasak olduğu gibi üretimin bazı dönemlerde tamamının devletçe kullanıldığı anlaşılmaktadır. Dolayısıyla Küre madenleri temel alınarak Klasik Dönem'de Osmanlı madencilik sektöründe de diğer sektörlerde olduğu gibi iaşe ve fiskalizm ilkelerinin uygulandığını söyleyebilmekteyiz.

\section{Sonuç}

Kapitalizm öncesi yapıdaki sosyoekonomik formasyonlarda bazı iktisadi zihniyet ilkeleri geçerli olmuştur. Osmanlı Devleti için bu ilkelerin iaşe, gelenekçilik ve fiskalizm olduğu kabul edilmektedir. İaşe ilkesi tüketiciye öncelik verilerek devletin sıkı müdahalesiyle mal ve hizmet arzının mümkün olan en yüksek düzeyde tutulması, gelenekçilik ilkesi iktisadi düzlemde

\footnotetext{
${ }^{15}$ İbriklere barutun üretim sürecinde kullanılan güherçile konulmuştur.
} 
mevcut düzenin korunarak geleneksel kuralların gözetilmesi ve fiskalizm ilkesi iktisadi faaliyetlerde devlet gelirlerinin mümkün olduğu kadar yüksek düzeye çıkarılması ve ulaştı̆̆ düzeyin altına inmesinin engellenmesi amacının güdülmesi şeklinde tanımlanabilir.

Antik Çağ'dan itibaren Orta Doğu toplumlarında iktidarın meşrulaş̧ııılmasında yararlanılan ideolojik söylemlerden geleneksel olarak en geçerli olanı adalet kavramı Osmanlı literatüründe "daire-i adliye" yani "adalet dairesi" olarak ifade edilmiştir. Kapalı devreye benzemekte olan bu kavramın unsurları; devlet, asker, servet (hazine), halk ve adalettir. Söz konusu kavramın Osmanlı iktisadi zihniyet ilkelerinin birleştirici bir ruhu niteliğinde olduğu kabul edilebilir.

Çalışmada Klasik Dönem'de Osmanlı zanaatları dokumacılık, dericilik ve madencilik başlıkları altında incelenmiştir. Bu ayrım Osmanlı Devleti'nde başka zanaat grubunun bulunmadığı anlamına gelmemektedir. Nitekim Osmanlı şehir çarşılarında gıda üretimiyle ilgili zanaatlar da önemli bir yere sahip olmuştur. Bunun dışında Osmanlı Devleti'nde "piyasanın karşııtı pazar"da zanaat gruplarının işleri için ihtiyaç duydukları ham maddelerin tedarik edilmesiyle bağlantılı olarak tedarikçilerin tarımsal üreticiler olduğu göz önünde bulundurulduğunda Osmanlı zanaat ve tarımsal üretimleri arasında bütünleşik bir ilişkinin geçerli olduğu da unutulmamalıdır.

Elde edilen temel sonuç Klasik Dönem'de Osmanlı zanaat üretiminin iktisadi zihniyet ilkeleri çerçevesinde yürütüldüğüdür. Adalet dairesi söz konusu ilkeleri birleştirici bir ruha sahip olmuştur. Adalet dairesinin unsurları kapalı bir devre algısı yaratsa da mantıksal olarak bakıldığında üreticiler tarafından üretilen servetin bütünüyle devlet masraflarına gitmediği yani bir "kaçak" olduğu görülmektedir. Bu kaçağın iktidarın ekonomik yönden refahının ve istikrarının sağlanılması ve bu kapsamda İstanbul'un ekonomik refahı ve istikrarı yönünde kullanıldığı anlaşılmaktadır. Bunun sebebi de tersi durumda iktidara yönelik ayaklanma gibi tehlikeli durumların ortaya çıkabileceğinin düşünülmesidir. Bu çalışmada incelenmeyen tarımsal üretimin de belirtilen zihniyet ilkeleri çerçevesinde sürece dâhil olduğu dikkate alındığında bu tespitimiz daha anlaşılır hale gelecektir ${ }^{16}$.

Diğer bir sonuç, kapitalizm öncesi yapılarda toplumsal artığa iktidar tarafından ekonomi dışı zor yoluyla el konulmasının Klasik Dönem'de Osmanlı Devleti için de geçerli olduğudur. Bu geçerlilik, iktisadi zihniyet ilkeleri çerçevesinde piyasa benzeri yapılara devletin müdahalesi bağlamında ya da ilgili zanaat üretiminin doğrudan devletin ihtiyaçları için üretim yapmaya zorlanması şeklinde gerçekleşmiştir.

\section{Kaynakça}

\footnotetext{
16 İstanbul'un iaşesini sağlamak Osmanlı devletinin en önemli konularından olduğu için özellikle hububat ticaretine kısıtlamalar getirilmiştir. İstanbul'un iaşesinde ekmek gibi et (başta koyun eti) temel gıda maddesi olmuştur. Bu yüzden et ve buğday tedariki her zaman önemli olmuştur. İstanbul'un bütün üretim bölgelerinin üretim fazlalarının akması gereken bir alan olarak görülmesi şehri imtiyazlı bir ticaret bölgesi haline getirmiştir. $\mathrm{Bu}$ sayede İstanbul daima canlı bir ticaret bölgesi olmuştur. Başkentin zaman zaman yiyecek sıkıntısı da yaşamasına rağmen yiyecek tedarikini güvence altına alan devletçi rejim sayesinde gerçek bir darlık yaşamamıştır. Merkezî yönetim, her eyalete başkente göndermeleri zorunlu gıda ve ham maddelerin neler olduğunu bildirmiştir. İstanbul'a buğday, et ve erzak Rumeli ve Marmara sahillerinden, Kefe'den yağ, Mısır'dan pirinç ve mercimek getirilmiştir. Devlet İstanbul'un iaşesi için, fazla hububatın İstanbul'a sevkini talep etmiştir. Bu kapsamda hububatı İstanbul'a tahsis edilen bölgeler tespit edilmiş, bunlar ile İstanbul arasında yapılacak hububat ticaretine de bir takım kısıtlamalar konulmuştur. İstanbul'a gerekli olan hububat Eflak ve Boğdan eyaletleri ile Tuna iskeleleri ve Karadeniz'in Rumeli yakasındaki iskelelerinden, Trakya'dan, Ege'nin Rumeli sahilleri ve Anadolu'da Kocaeli ve Karesi illerinden getirilmiştir. Bununla beraber meydana gelen darlık buhranları sırasında Kefe'den, Trabzon ve Samsun iskeleleri vasıtası ile, Erzurum ve Sivas'tan hububat getirilmiştir. Bunlar gibi Maraş ve Diyarbekir'den gelen canlı hayvanlar, Kefe'den gelen yağ, Karadeniz'den gelen sade yağ ve kuyruk yağı, İzmir ve Misır'dan gelen pirinç, mercimek, şeker, nohut, bakla ve bulgur hep İstanbul'a tahsis edilmiştir. Tekirdağ önemli bir ticaret merkezi olup; buradaki iskelelerden İstanbul'un iaşesine katkıda bulunulmuştur (Tabakoğlu, 2014: 101-3).
} 
Bozpinar, C. (2020), "Klasik Dönem Osmanlı Zanaatları: İktisadi Zihniyet İlkeleri Çerçevesinde Bir Değerlendirme", Politik Ekonomik Kuram, 4 (2), 270-280.

Aktar, A. (1990). Kapitalizm, az gelişmişlik ve Türkiye'de küçük sanayi. İstanbul: Afa Yayıncilik.

Altun, D. (2007). XIX. yüzyılda Bursa'da ipek böcekçiliği. Balıkesir Üniversitesi FEF Karesi Tarih Kulübü Bülteni. Erişim http://karesitarih.balikesir.edu.tr/8_ipek_bocegi.pdf.

Aynural, S. (2001). Kapan. İçinde Türkiye Diyanet Vakfi islam ansiklopedisi (cilt 24, 338-9). Erişim http://www.islamansiklopedisi.info/index.php.

Barkan, Ö. L. (1980). Türkiye'de toprak meselesi: Toplu eserler 1. İstanbul: Gözlem Yayınları.

Berkes, N. (2013). Türkiye iktisat tarihi. İstanbul: Yapı Kredi Yayınları.

Berkes, N. (2017). Felsefe ve toplumbilim yazıları. İstanbul: Yapı Kredi Yayınları.

Bozpinar, C. (2018). Osmanlı Devleti'nde iktisadi zihniyet ve sanayileşme sorunsall: Bursa ipek sektörü örneği (Yayımlanmamış doktora tezi). Hacettepe Üniversitesi Sosyal Bilimler Enstitüsü, Ankara.

Çelik, K. (2016). Osmanlı idaresindeki Lübnan'da ipek üretimi ve ticareti üzerine bir değerlendirme. Firat Üniversitesi Sosyal Bilimler Dergisi, 1 (26), 277-90.

Dalsar, F. (1960). Türk sanayi ve ticaret tarihinde Bursa'da ipekçilik. İstanbul: İstanbul Üniversitesi Yayınları.

Faroqhi, S. (2002). İktisat tarihi: 1500-1600. İçinde (Ed.) S. Akşin, Türkiye tarihi 2: Osmanlı Devleti (1300-1600) (7. bask1). İstanbul: Cem Yayınevi. 145-205.

Faroqhi, S. (2008). Osmanlı dünyasında üretmek, pazarlamak, yaşamak (3. baskı). (Çev. G. A. Güven ve Ö. Türesay). İstanbul: Yapı Kredi Yayınları.

Faroqhi, S. (2014). Osmanlı'da kentler ve kentliler: Kent mekâninda ticaret, zanaat ve glda üretimi 1550-1650 (5. baskı). (Çev. N. Berktay). İstanbul: Tarih Vakfı Yurt Yayınları.

Faroqhi, S. (2017). Osmanlı zanaatkârlart: Imparatorluk döneminde zanaatlar ve loncalar. (Çev. Z. Kılıç). İstanbul: Alfa Yayınları.

Genç, M. (2012). Osmanlı iktisadi dünya görüşünün ilkeleri. İçinde Osmanlı İmparatorluğunda devlet ve ekonomi. İstanbul: Ötüken Neşriyat. 45-69.

Haldon, J. (1993). The state and the tributary mode of production. Verso: London \& New York.

İnalcık, H. (2009). Osmanlı İmparatorluğu'nun ekonomik ve sosyal tarihi 1 (3. baskı). (Çev. H. Berktay). İstanbul: Eren Yayıncılık.

İnalcık, H. (2013). Osmanlı İmparatorluğu Klâsik Çă̆ (1300-1600). (Çev. R. Sezer). İstanbul: Yapı Kredi Yayınları.

Keyder, Ç. (1989). Türkiye'de Devlet ve Sinfflar (S. Tekay, Çev.). İstanbul: İletişim Yayıncılık.

Kıvrım, İ. ve Elmacı, S. (2011). Osmanlı döneminde Amasya'da ipekçilik. Turkish Studies: International Periodical for the Languages, Literature and History of Turkish or Turkic, 4 (6), 715-28.

Lewis, B. (2011). Çatı̧̧an kültürler: Keşifler çağında Hıristiyanlar, Müslümanlar, Yahudiler (5. baskı). (Çev. N. Elhüseyni). İstanbul: Tarih Vakfı Yurt Yayınları.

Öz, M. (1999). Klasik Dönem Osmanlı siyasi düşüncesi: Tarihi temeller ve ana ilkeler. İslami Araştırmalar Dergisi, 1 (12), 27-33. 
Bozpinar, C. (2020), "Klasik Dönem Osmanlı Zanaatları: İktisadi Zihniyet İlkeleri Çerçevesinde Bir Değerlendirme", Politik Ekonomik Kuram, 4 (2), 270-280.

Özcan, T. (2007). Pazar. İçinde Türkiye Diyanet Vakfi islam ansiklopedisi (cilt 34, 206-8). Erişim http://www.islamansiklopedisi.info/index.php.

Özkul, A. E. (2010). Osmanlı idaresinde Kıbrıs adasında yapılan ziraat ve hayvancılık. İçinde Birinci İktisat Tarihi Kongresi tebliğleri 2. İstanbul: İstanbul Ticaret Odası Yayınları. 283-95.

Özveren, E. (2007). Bazaars of The Thousand and One Nights. The European Journal of The History of Economic Thought, 14 (4), 629-55.

Pamuk, Ş. (2010). Osmanl-Türkiye iktisadi tarihi: 1500-1914 (6. baskı). İstanbul: İletişim Yayınları.

Sahtiyan. (t.y.). İçinde Türk Dil Kurumu Güncel Türkçe Sözlük. Erişim http://www.tdk.gov.tr.

Şahin, R. (2006). Edirne gümrüklerine göre XVIII. Yüzyllın ikinci yarısinda Edirne'de ticari hayat (Yayımlanmamış yüksek lisans tezi). Trakya Üniversitesi Sosyal Bilimler Enstitüsü, Edirne.

Şimşirgil, A. (1995). XV-XVI. asırlarda Tokat şehrinde iktisadi hayat. Tarih İncelemeleri Dergisi, 1 (10), 187-210.

Tabakoğlu, A. (2000). Türk İktisat Tarihi (5. bask1). İstanbul: Dergâh Yayınları.

Tabakoğlu, A. (2014). Osmanlı Döneminde İstanbul'un iaşesi. İçinde (Eds) Emecen, F. M., Akyıldız, A. ve Gürhan, E. S. Osmanlı İstanbulu II. 99-148.

Tekin, K. H. (2013). Osmanlı hâkimiyeti döneminde Halep şehrindeki ticari yapılanma. The Journal of Academic Social Science Studies, 8 (6), 681-98.

Ülgener, S. F. (2006). Tarihte darlık buhranlart ve iktisadi muvazenesizlik meselesi. İstanbul: Derin Yayınları.

Yılmaz, H. F. (2012). 16. Yüzyılda Osmanlı ekonomisinde 'piyasa'nın karşıtı 'pazar'. İstanbul: Ötüken Neşriyat.

Yurtseven, Y. (2009). Osmanlı Klasik Döneminde ideoloji, din ve siyasi meşruiyet üzerine kısa bir değerlendirme. Gazi Üniversitesi Hukuk Fakültesi Dergisi (Yrd. Doç. Dr. İbrahim ONGÜN'e Armă̆an), 1-2 (11), 1255-84. 